\title{
Queensland Review
}

http://journals.cambridge.org/QRE

Additional services for Queensland Review:

Email alerts: $\underline{\text { Click here }}$

Subscriptions: $\underline{\text { Click here }}$

Commercial reprints: $\underline{\text { Click here }}$

Terms of use : $\underline{\text { Click here }}$

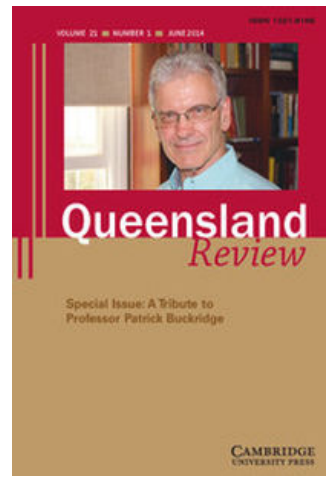

\section{Live! Queensland band culture exhibition, State Library of Queensland, May-November 2013}

Brydie-Leigh Bartleet

Queensland Review / Volume 21 / Special Issue 01 / June 2014, pp 115 - 116

DOI: 10.1017/qre.2014.16, Published online: 08 May 2014

Link to this article: http://journals.cambridge.org/abstract_S1321816614000166

How to cite this article:

Brydie-Leigh Bartleet (2014). Queensland Review, 21, pp 115-116 doi:10.1017/qre.2014.16

Request Permissions : $\underline{\text { Click here }}$ 
and points of departure for those wishing to pursue the tangents of his account. The manuscript itself, in its depiction of frontier life, does not disappoint in its detail of adventures, moments of contact and conflict, and observations that tell us just as much about Goldie's character as what he is observing - using, of course, the language of the times. There are also detailed descriptions of the specimens and objects he saw and collected, and often details of how these were used in their traditional context. The manuscript unfortunately ends abruptly, but the chapter closes with an editorial note directing the reader to a source for Goldie's account of his next expedition, thus offering some continuity.

Chapter 4, by Susan M. Davies, picks up on the detail of Goldie's artefact collecting, providing an overview of the range of objects Goldie collected, his methods of collecting and the institutions that came to house his collections. A not insignificant amount of his specimens eventually made their way to the Queensland Museum, a collection that Davies has worked on comprehensively. This chapter concludes with an extensive appendix listing the objects collected by Goldie that were acquired and/or exhibited by institutions in Australia and New Zealand.

Chapter 5, also by Davies, consists of a catalogue of artefacts associated with Goldie that are held in the Queensland Museum and the Museum of the Cumbraes, Millport, Scotland. This is really a jewel in the crown of this publication: the comprehensive overview, complemented by fascinating black and white photographs, gives way to individual records of items complete with stunning colour imagery. This chapter brings to life Goldie's manuscript accounts of the objects he encountered, and is a dream for anyone interested in the material culture of the Pacific.

Two beautifully presented maps of New Guinea in 1890 in the back cover round off an impressive publication. The small imperfections, such as the lack of contributor information, a handful of typographical errors and some repetition between chapters (obviously designed to be able to stand alone) do not detract from the value of this publication. The text is admirable in its ability to appeal to a wide and cross-disciplinary audience: it will appeal to historians, museum curators, natural history specialists, anthropologists and, of course, the generalist reader interested in the colonial history of Australia and New Guinea, and the role that Queensland played in it, during the late nineteenth century.

Kirsty Gillespie

doi $10.1017 /$ qre.2014.16

Live! Queensland band culture exhibition, State Library of Queensland, May-November 2013

This was the kind of exhibition that left a lasting impression. It moved you to tears, left you silently grinning and had you grooving to the music of Queensland's bands all within the blink of an eye. It opened up an engaging and exciting space for visitors to learn about the state's musical soundtrack, and reflect on the tremendous role that band musicians have played in shaping our history. 
I don't use the word 'engaging' lightly. There really was something of interest for everyone in this exhibition. The very spirit of community engagement that has underpinned so much of Brisbane's band history was certainly very present in the way this exhibition was curated. I visited it on multiple occasions: one time to meander through the exhibition spaces; on another occasion to participate in 'A Night in the JOL' about Queensland's band history; and yet another time with my two-year-old twins, who revelled in trying on some of the band outfits in the children's section. Each time, I took away a new insight, and a deeper appreciation of how significant these musicians and bands have been in influencing and sharing Queensland's social, cultural and political stories.

The exhibition ran for six months (May-November 2013), and featured live performances, exhibitions, talks, workshops and film, showcasing Queensland's bands from the 1850s to the present day. The exhibition spanned many different genres, from traditional brass bands to the jazz era and grunge, among others. It not only featured the bands themselves, but also the stories of the fans and venues through photographs, memorabilia, digital stories and displays.

The Deadly Brothers exhibition also celebrated Murri men who have played pivotal roles in Queensland's music history from rock to electronic music and opera. The Sunday sessions featured an impressive line-up of free performances, and workshops in songwriting, music business and video editing offered budding musicians the opportunity to develop their skills. The program also featured free films, Tea and Music sessions and the Music Box, a multi-faceted pop-up venue. In each of these spaces and events, evocative threads of cultural connection, social rebellion, and the impact of venues and new technologies were cleverly woven through. This made for an illuminating social commentary about arts and culture in Queensland more broadly.

The magnitude of this exhibition and the array of spaces and associated events sometimes felt overwhelming, but when you stepped back for a moment it was the small things - the intimacy of the faces, stories, memorabilia and sounds - that stood out as the most memorable. Like many visitors, I suspect, I recognised a number of the faces and the soundtracks, having conducted some of the musicians and bands featured in Live! As I looked at their photographs and memorabilia, I was moved to tears by the sensitive and respectful way their lives in music were captured and celebrated in this exhibition. It wasn't just about showcasing our state's high-profile music stars, but also acknowledging those uncelebrated heroes who have been playing band music in the community for so many years.

Bravo to the State Library of Queensland team for curating this exhibition and telling the stories of Queensland's band history with such care and creativity.

Brydie-Leigh Bartleet 